\title{
Virulence factors involved in the pathogenesis of bovine intramammary infections due to Staphylococcus aureus
}

\author{
L. SUTRA and B. POUTREL* \\ Université d'Angers, Faculté des Sciences, 2 Boulevard Lavoisier, 49045 Angers Cedex and * Institut National de la \\ Recherche Agronomique, Laboratoire de Pathologie Infectieuse et d'Immunologie, 37380 Nouzilly, France
}

\begin{abstract}
Summary. Staphylococcus aureus is a major causative agent of intramammary infections in dairy cows. In this report, the pathogenesis of these infections is described. The potential role in virulence of $S$. aureus surface components (adhesins, protein A and capsular polysaccharides), toxins, extracellular enzymes and coagulase, and perspectives for the development of an efficient vaccine are discussed.
\end{abstract}

\section{Introduction}

Staphylococcus aureus is a gram-positive, facultatively anaerobic, non-sporulating, non-motile, catalase-positive and oxidase-negative coccus. ${ }^{1}$ This bacterium, which is a natural inhabitant of mammalian skin and mucous epithelia, is the causative agent of various diseases in man and domestic animals.

In man, $S$. aureus causes two main types of infection: ${ }^{2}$ (1) cutaneous or mucosal infections, and (2) septicaemic infections which are generally associated with visceral (abscesses, endocarditis, lung infections) or bone (osteomyelitis) infections.

In domestic animals, $S$. aureus is mainly involved in intramammary infections (IMI) of lactating females. ${ }^{3}$ In cows, IMI due to $S$. aureus, which account for $25-30 \%$ of total IMI, ${ }^{4}$ are generally subclinical. Nevertheless, IMI cause considerable economic losses, particularly milk losses which range from 10 to $25 \%$ of total yield according to the intensity of inflammation and the stage of lactation when the infection occurs. ${ }^{3}$ Moreover, the presence of $S$. aureus in raw milk used by dairy industries is a public health problem.

\section{Current control of intramammary infections}

At present, the control of $S$. aureus IMI is based on two types of measures. ${ }^{5}$ Firstly, hygiene at milking that aims to limit the spread of IMI in herds, particularly pre-milking washing and post-milking drying of udders with individual cloths, dipping teats with antiseptic solutions after milking, and cleaning of milking machines. Secondly, systematic antibiotic treatment by the intramammary route at drying-off to cure chronic subclinical IMI established during lactation and to prevent new infections during the dry period.

In practice, these measures, which are often considered constraining or expensive, are not always applied on the farm. The presently available antibiotic preparations used during lactation cure $<50 \%$ of $S$. aureus IMI. ${ }^{6}$ This low efficiency seems not to be due to acquired resistance but may result from the fact that some bacteria are located intracellularly, in macrophages or epithelial cells, and inaccessible to antibiotics.

In the context of the high prevalence and economic consequences of $S$. aureus IMI, and the relative inefficiency of control measures, the development of a vaccine against $S$. aureus IMI is of great interest. Numerous attempts at vaccination with live or killed bacterial cells, isolated bacterial cell walls, toxoid or killed cell-toxoid preparations, have been made. ${ }^{7,8}$ In several experiments, particularly those with toxoids, a reduction of the frequency and the severity of clinical IMI has been observed. However, whatever the antigenic preparations used, protection against new infections, which is the main objective of vaccination, has never been achieved. Three major reasons can be invoked to explain these results: ${ }^{9}$ (1) an incomplete knowledge of the immune defence mechanisms of the mammary gland; (2) the fact that vaccine prepared in vitro did not contain relevant antigens, i.e., those expressed in vivo and involved in virulence; and (3) the lack of appropriate immunisation schedules.

The development of a vaccine against a bacterial infection requires a clear definition of the major

Received 15 Feb. 1993; revised version accepted 27 July 1993. 
virulence factors involved in the infection. Molecular genetics permits the isolation of specific genes from bacterial pathogens, the elucidation of their structure and function and the modification of their expression. A powerful approach based on Koch's postulates has been proposed as follows. ${ }^{10}(1)$ The supposed virulence factor should be associated with pathogenic strains of the bacterial species under investigation. (2) The gene(s) encoding this supposed virulence factor should be isolated and the inactivation of the gene(s) should lead to a significant loss of virulence. (3) The reintroduction of the gene(s) of origin in the modified strain(s) should restore the virulence. During the past decade, this modern molecular approach has been developed to study virulence factors of $S$. aureus isolates from bovine IMI.

The purpose of this article is to review the current knowledge on the virulence factors involved in the pathogenesis of bovine $S$. aureus IMI and examine the prospects for a vaccine against these infections.

\section{Contamination of the teat orifice and entry of $S$. aureus into the mammary gland}

Intramammary infections caused by $S$. aureus, and also by other bacterial species, are due to the entry of bacteria through the teat canal into the mammary gland. One quarter of a cow's udder is generally infected independently of the other three.

The main reservoirs of $S$. aureus in herds are infected quarters and the skin of the udder and teats. ${ }^{5,11}$ The presence of lesions on teat skin, such as chaps and cracks, allows persistent colonisation of the skin by $S$. aureus. A study on $c .800$ quarters has shown that without hygienic measures during milking, the rate of teat orifice contamination by $S$. aureus can reach $60 \%$ of healthy quarters compared to $>85 \%$ of quarters with teat skin lesions. ${ }^{12}$ To avoid teat trauma or lesions due to adverse milking conditions, the vacuum level and pulsation frequency of milking machines must be checked regularly and adjusted.

As $S$. aureus is mainly located on or in udders, the transmission of bacteria from teat to teat in the same cow or from one cow to another generally occurs during milking. The main vectors of transmission are the hands of milking staff, the cloths used to wash or dry the udder, the milking cups and contaminated milk which can flow back to the teat during milking as a consequence of sudden variations of vacuum in the milking machine (impact phenomenon). ${ }^{5}$ The role of milking in the transmission of $S$. aureus is confirmed by the fact that rigorous hygienic measures during milking lead to a drastic decrease in teat orifice contamination and, consequently, in the rate of new $S$. aureus IMI in herds. ${ }^{12,13}$

Once the teat orifice is contaminated by $S$. aureus, bacteria can persist and multiply ${ }^{14}$ and then enter the teat canal either by progressive colonisation or by the impact phenomenon, particularly at the end of milking. ${ }^{3}$ Colonisation of the teat canal seems to be a necessary preliminary step for the mammary gland to be infected. ${ }^{15} S$. aureus, together with coagulasenegative staphylococci, Corynebacterium bovis and Streptococcus agalactiae, are the micro-organisms most frequently isolated from the teat canal ${ }^{16}$ where they can adhere to the keratinised epithelial cells. ${ }^{17.18}$ It seems that the closer the bacteria colonising the teat canal are to the teat sinus, the higher is the risk of mammary infection..$^{19}$ The contact of these bacteria with milk could allow their transfer into the teat sinus when the intramammary pressure increases (before milking or when the cow walks, lies down or stands up) and just after milking when the teat canal is distended. ${ }^{3,20}$

\section{Colonisation of the mammary gland}

Several studies have shown that it is possible to induce experimental $S$. aureus IMI by intramammary infusion of a low number of bacteria $(<100 \mathrm{cfu})$ through the teat canal. ${ }^{21,22}$ These observations demonstrate that milk is a good medium for growth of $S$. aureus, which can hydrolyse casein and ferment lactose, ${ }^{1}$ and that the natural defence mechanisms of the mammary gland against infection are inefficient. Bacterial surface properties play a major role in the host-bacterium relationship. ${ }^{23}$ During $S$. aureus IMI, surface components participate in bacterial adhesion to host mammary tissues and to resistance to phagocytosis by milk cells.

\section{Role of adhesins}

The first step in the colonisation of the mammary gland by $S$. aureus seems to be adhesion to epithelial cells. The in-vitro adhesion of $S$. aureus to bovine mammary epithelial cells was demonstrated initially by Frost ${ }^{24}$ and then confirmed by other authors. ${ }^{25}$ This phenomenon varies with the strain and with the origin of the cells. The adhesive ability of a strain varies little when epithelial cells come from the different quarters of the same cow but greatly when cells come from the udders of different cows. ${ }^{26,27}$ The attachment of $S$. aureus to epithelial cells of lactiferous ducts has been confirmed in vivo by microscopic examination of sections of experimentally infected mammary glands. ${ }^{28}$ The mechanisms of $S$. aureus adhesion to mammary epithelial cells are not well known. Two types of interactions could be involved: (1) non-specific physiochemical interactions, and (2) specific interactions between bacterial cell-wall-associated receptors and host components.

Most $S$. aureus isolates from bovine IMI have a high surface hydrophobicity which can vary from strain to strain and with the culture medium..$^{29,30}$ This surface characteristic could favour the fixation of bacteria to host cells through hydrophobic interactions with the cell membrane. Moreover, $S$. aureus can bind to host 
extracellular proteins such as collagen ${ }^{31}$ and fibronectin (Fn). ${ }^{32}$ In strains of human origin, a relationship between invasiveness (i.e., the ability to travel through the blood stream or tissues to cause disease), adhesion in in-vitro systems and quantitative expression of receptors to Fn has been reported. ${ }^{33}$ The Fn-binding receptor of $S$. aureus has been identified as a protein of $c .200 \mathrm{kDa}^{34}$ In fact, two different closely linked genes encoding two structurally related Fnbinding proteins (Fnbp) have been recently described and amino-acid homologous units (called D1-D4) have been defined as the Fn-binding domain on these proteins. ${ }^{35,36}$ Receptors for collagen and Fn have also been demonstrated on strains isolated from bovine IMI ${ }^{37,38}$ However, the role of Fnbp in the virulence of $S$. aureus during IMI has not been definitively demonstrated. Molecular biology could provide the tools to clarify this point. As the complete sequences of the genes encoding Fnbp are well established, ${ }^{35,36}$ it will be possible to isolate mutants lacking Fn-binding ability by site-specific mutagenesis. These mutants could be used in experiments such as in-vitro adhesion to mammary cells and experimental IMI in cows. It is noteworthy that the surface components of $S$. aureus that mediated adhesion either by hydrophobic interactions or by specific recognition of host components are proteins. Adherence of $S$. aureus to ductular cells in vitro is inhibited when bacteria are first treated with proteolytic enzymes. ${ }^{39}$ These enzymes also decreased surface hydrophobicity ${ }^{29}$ and the ability of $S$. aureus to bind collagen ${ }^{31}$ and Fn. ${ }^{37}$ Recently, Lindahl et al. ${ }^{40}$ purified a cell-wall associated protein of $145 \mathrm{kDa}$ from a strain of $S$. aureus isolated from bovine IMI. This component has the ability to bind to membrane proteins of bovine milk fat globules and mammary epithelial cells.

From facts already known, it can be supposed that adhesins such as Fnbp could mediate $S$. aureus adhesion to epithelial cells and to micro-lesions of the mammary epithelium where basal lamina and inflammatory conjunctive tissue, which are rich in Fn and collagen, are exposed. ${ }^{37}$ In the early stages of the infection, adhesion to epithelial cells could prevent $S$. aureus from flowing out of the gland during milking. Then, $S$. aureus could disseminate in the mammary gland by adhering to rising fat globules ${ }^{17,41}$ and then attach to the epithelial cells at different levels of the gland, i.e., teat sinus and lactiferous sinus and ducts. ${ }^{26}$

\section{Expression of antiphagocytic factors by $S$. aureus}

The main defence mechanism of the mammary gland against infections by $S$. aureus is phagocytosis by polymorphonuclear neutrophil leucocytes (PMNL) ${ }^{42}$ Schalm et al. ${ }^{43}$ have demonstrated that the induction of neutropaenia by continuous intravenous injection of equine anti-bovine leucocyte serum led to a conversion of $S$. aureus IMI from subclinical to the acute gangrenous form. Moreover, Postle et al. ${ }^{22}$ failed to induce experimental $S$. aureus IMI in quarters with milk somatic cell counts (SCC) greater than $6 \times 10^{5}$ cells $/ \mathrm{ml}$.

The SCC of milk from healthy quarters is generally $<10^{5}$ cells $/ \mathrm{ml}$. Infection of the mammary gland entails a flow of leucocytes, mostly PMNL, from blood through the mammary parenchyma into milk. ${ }^{\mathbf{4 4}}$ After experimental intramammary inoculation with $S$. aureus, the SCC of milk begins to increase $1-3 \mathrm{~h}$ after inoculation and can reach several million cells $/ \mathrm{ml}$ within $24-48 \mathrm{~h}^{28,45}$

Phagocytosis of bacteria by PMNL includes recognition, ingestion and intracellular destruction of bacteria. ${ }^{46}$ Membrane receptors of PMNL can bind non-specifically to bacterial surface components through lectin-carbohydrate-like interactions but recognition of bacteria and subsequent activation of PMNL are much more efficient when they are mediated by opsonins. Opsonisation of $S$. aureus involves antibodies, particularly those specific to peptidoglycan epitopes, and the $\mathrm{C} 3 \mathrm{~b}$ component of complement. ${ }^{47}$ The $\mathrm{C} 3 \mathrm{~b}$ component is generated by activation of complement by the classic or alternate pathways, either directly by surface components of $S$. aureus such as peptidoglycan or teichoic acid, ${ }^{48}$ or by immune complexes between peptidoglycan and specific antibodies, particularly of the IgG isotype. ${ }^{47}$ Fixation of immunoglobulins (associated to $\mathrm{C} 3 \mathrm{~b}$ or not) by their antibody site on bacteria and by their Fc fragment on PMNL surface receptors activates the ingestion of bacteria by PMNL. In ruminants, most of the membrane Fc receptors on PMNL are specific to IgG2 isotype. ${ }^{49,50}$

The milk of a healthy quarter has a low concentration of opsonins, complement ${ }^{51}$ and immunoglobulins $(0 \cdot 8-1 \mathrm{mg} / \mathrm{ml}$, i.e., $25-30$ times less than in serum). ${ }^{52}$ The milk content of IgG2, which is the major isotype involved in opsonisation, is particularly low $(0.05-0.06 \mathrm{mg} / \mathrm{ml})$. The inflammation of the mammary gland during $S$. aureus IMI includes both PMNL recruitment and exudation of plasma through the mammary parenchyma into milk. Milk concentrations of IgG1, IgG2 and complement increase. ${ }^{53-55}$ Nevertheless, this inflammation does not result in the total elimination of bacteria but only in a partial control of the infection which evolves to a chronic subclinical form that reflects a balance between multiplication of bacteria and the mammary defences. This balance can be explained on one hand by the low efficiency of phagocytosis due to the ingestion of casein and fat globules by PMNL ${ }^{56,57}$ and to the low level in milk of opsonising antibodies specific to $S$. aureus and, on the other hand, by the production of antiphagocytic factors such as protein $\mathrm{A}$ and a capsule by $S$. aureus.

Protein A. Staphylococcal protein A (SpA) is a protein bound to the surface of the bacterial cell wall that has the ability to bind IgG of numerous mammalian species (man, mouse, rabbit, ruminants) by the Fc fragment. ${ }^{58,59}$

Using human IgG as a source of opsonins, Dossett et al. ${ }^{60}$ have demonstrated that bacterial bound or free 
soluble $\mathrm{SpA}$ inhibited phagocytosis of $S$. aureus by human PMNL in vitro. Nevertheless, this antiphagocytic effect seems to depend on the relative availability of both antibodies and complement. In the presence of human IgG-deficient serum, opsonisation of $\mathrm{SpA}$ high-producing strains is more efficient than that of low-producing strains whereas the converse has been observed with normal human serum or purified IgG as opsonins. ${ }^{60,61}$

SpA, which has been detected on $50-60 \%$ of strains isolated from bovine IMI, ${ }^{62,63}$ can react strongly with bovine IgG2, but weakly with IgG1 ${ }^{64}$ In milk from a healthy quarter, the concentration of IgG2, the major isotype involved in opsonisation, is very low. Consequently, SpA may play a minor role in $S$. aureus virulence, at least during the early stages of bovine IMI. Postle et al. ${ }^{22}$ reported a highly significant negative correlation between the amount of $\mathrm{SpA}$ on $S$. aureus strains (12 strains studied) and their experimental pathogenicity in cows. This was postulated to be due to complement activation by $\mathrm{SpA}$ that released chemotactic (C3a and $\mathrm{C} 5 \mathrm{a}$ components) and opsonising (C3b) factors. Conversely, during later stages of IMI when the opsonising IgG2 milk content increases as a consequence of plasma inflammatory exudation, the antiphagocytic effect of $\mathrm{SpA}$ could be expressed. Nevertheless, this hypothesis has still to be proved. Finally, it is noteworthy that Jonsson et al ${ }^{65}$ observed no difference in virulence for the mouse mammary gland between an SpA low-producing strain, a high-producing mutant and a SpA-negative mutant carrying a plasmid containing the complete gene for SpA. With the same mouse model, Foster et $a l .{ }^{66}$ observed that $\mathrm{SpA}$-deficient mutants were less virulent than a parental strain that produced a high amount of SpA. The discrepancy between these two studies could be due to the method used to isolate mutants - chemical mutagenesis, that can induce pleiotropy in the former study and site-specific mutagenesis in the latter one.

Capsule. The capsule is defined as a polysaccharide layer covering the cell wall. ${ }^{67}$ When observed by light or electronmicroscopy in the presence of Indian ink, it appears as a white halo surrounding the bacteria. ${ }^{68}$ Capsulate $S$. aureus strains produce diffuse colonies in serum-soft agar (SSA), a medium containing normal rabbit serum $1 \%$, whereas non-capsulate strains produce compact colonies. ${ }^{69}$ Two studies (each with about 800 strains) have demonstrated that only $5 \%$ of $S$. aureus strains isolated from human infections produce a capsule as defined by the microscopic Indian ink and the SSA techniques. ${ }^{70,71}$

The existence of a capsule on $S$. aureus strains isolated from bovine IMI is a much debated matter. Several studies have shown that most strains (85-95\%) produce diffuse colonies when inoculated directly from infected milk into SSA. ${ }^{72-74}$ In these studies, SSA was prepared from a modified staphylococcus medium 110 (mod 110) which is enriched with mannitol, lactose and sodium chloride and is known to enhance the production of extracellular polysaccharides by $S$. aureus. ${ }^{69}$ Nevertheless, the reliability of the SSA technique for demonstrating capsulation has been contested. On strains isolated from IMI that produced diffuse colonies in SSA, Anderson ${ }^{75}$ and Rather et al. ${ }^{76}$ failed to observe a capsule by light microscopy. They concluded that strains from bovine IMI were not capsulate ${ }^{75}$ or that these strains do not produce capsule but slime, ${ }^{76}$ a polysaccharide component loosely bound to the bacterial surface. ${ }^{67}$

Watson's team in Australia has observed that $S$. aureus strains isolated from bovine or ovine IMI produce a surface component when cultivated in vivo in the peritoneal cavity of sheep but not in vitro in classical media, which they called a pseudocapsule. ${ }^{77,78}$ The pseudocapsule is associated with the bacterial surface but is not visible by light microscopy and, therefore, cannot be classified as a classical capsule. Watson and Watson ${ }^{79}$ demonstrated by electronmicroscopy that the pseudocapsule is also produced in vivo during IMI and in vitro when $S$. aureus is cultivated in nutrient broth containing bovine, ovine or caprine milk whey. However, this pseudocapsule has never been purified and its biochemical nature and structure have never been demonstrated. Therefore, it cannot be related to the well defined capsular polysaccharides described by Karakawa and $\operatorname{Vann}^{80}$ (see below). Strains producing a pseudocapsule are more virulent for mice and have a higher resistance to phagocytosis by PMNL. ${ }^{78}$ Vaccination of cows ${ }^{81}$ or ewes $^{82}$ with a pseudocapsule-producing strain induced serum pseudocapsular antibodies and increased the resistance of vaccinated animals to experimental infections by $S$. aureus, as assessed by the severity of clinical signs and milk production. However, pseudocapsular antigens used to detect antibodies induced by vaccination were prepared by abrasion of the vaccine strain surface with glass beads and removal of $\mathrm{SpA}$ by elution through an affinity column of Sepharose 4B to which purified rabbit IgG was coupled. ${ }^{81,82}$ It is likely that the extract is a complex multi-antigenic mixture and, consequently, the partial protection observed cannot be ascribed to any single factor.

It has been demonstrated that $S$. aureus strains isolated from human infections produce capsular polysaccharides (CP) that belong to 11 different serotypes. ${ }^{80,83}$ Several serological surveys with rabbit polyclonal sera $^{83,84}$ or mouse monoclonal antibodies (MAbs) ${ }^{85,86}$ have shown that $70-80 \%$ of strains from human sources belong to two serotypes, 5 and 8 . Types 5 and $8 \mathrm{CP}$ have been purified, ${ }^{87,88}$ visualised on bacterial surfaces by electronmicroscopy with goldlabelled $\mathrm{MAbs}^{85}$ and their chemical structures have been defined $:^{89}$ they are heteropolymers of $\mathrm{N}$-acetylfucosamine and $\mathrm{N}$-acetylmannuronic acid with $\mathrm{O}$ acetyl groups, the location of which varies according to serotype. These $\mathrm{CP}$ do not constitute classical capsules, i.e., visible by light microscopy, but microcapsules. Strains producing CP are resistant to phago- 
cytosis in vitro by human PMNL in the presence of heat-inactivated normal human serum but this resistance is suppressed in the presence of CP-specific rabbit serum or mouse MAbs. ${ }^{90}$

By using anti-type 5 and 8 MAbs, we have demonstrated recently that these $\mathrm{CP}$ types account for $>50 \%$ and for $c .20 \%$ of 212 S. aureus strains isolated from bovine IMI, respectively. ${ }^{91}$ These two CP types are also prevalent amongst $S$. aureus strains from caprine and ovine IMI. ${ }^{91}$ Most CP-producing strains exhibited diffuse colonies in mod 110-SSA with a masking of cell-wall-associated components such as SpA and teichoic acid. ${ }^{92}$ Nevertheless, no capsule was observed by the microscopic Indian ink technique. It seems that most $S$. aureus strains from IMI express a capsule that is sufficiently thick to mask bacterial surface antigen but not thick enough to be detected by light microscopy. ${ }^{93}$ After cultivation on bovine milk agar, $S$. aureus strains isolated from IMI become more resistant to phagocytosis in vitro by bovine PMNL in the presence of normal, i.e., complement-containing, bovine serum than after cultivation on conventional media. This resistance is also associated with cellsurface masking ascribable to $\mathrm{CP}$ expression, as demonstrated by agglutination with specific MAbs. ${ }^{94}$ With an enzyme-linked immunosorbent assay (ELISA), we have shown that normal bovine serum contains large amounts of anti-teichoic acid antibodies but very low amounts of anti-CP antibodies. ${ }^{94}$ Consequently, it can be concluded either that $\mathrm{CP}$ could act as a barrier to the binding of serum opsonins to $S$. aureus surface ${ }^{95}$ or, if the capsule is permeable to opsonins, as suggested previously, ${ }^{96} \mathrm{CP}$ could prevent their interaction with PMNL-specific membrane receptors. ${ }^{67}$ Our results are not consistent with those obtained by $\mathrm{Xu}$ et al. ${ }^{97}$ These authors have shown that type 5 and 8 micro-capsulate strains did not resist phagocytosis by human PMNL in the presence of normal human serum. These discrepancies could be explained by the fact that our experiments ${ }^{94}$ were performed with strains of bovine origin cultivated in the presence of milk that enhanced the expression of $\mathrm{CP}$, as demonstrated by the shielding of bacterial surface, whereas $\mathrm{Xu}$ et al.$^{97}$ used strains from man cultivated in conventional Columbia broth. In the latter case, it can be supposed that the microcapsule was not thick enough to impede the interaction between cell-wall associated $\mathrm{C} 3 \mathrm{~b}$ and receptors to $\mathrm{C} 3 \mathrm{~b}$ on PMNL.

\section{Hypothetic kinetics of in-vivo expression of S. aureus surface components}

Although the kinetics of expression of surface components have never been investigated, it can be supposed that during the first stages of infection $S$. aureus produces hydrophobic surface proteins, particularly receptors for host components, that allow it to adhere to mammary epithelium and milk fat globules and thus to disseminate in the gland..$^{29,30,40}$ Then, during exposure to milk, $S$. aureus could express
CP that prevents phagocytosis by impairing interactions between bacteria and PMNL mediated by opsonins as described above, ${ }^{67}$ or because of their hydrophilic nature. ${ }^{98}$ Expression of capsule by $S$. aureus during IMI has been demonstrated clearly by detection of CP by ELISA with MAbs in milk from infected mammary glands ${ }^{99}$ and by electronmicroscopy studies of strains separated from IMI milk samples by magnetic particles coated with anticapsulate $S$. aureus antibodies. ${ }^{100}$

These hypotheses are supported by the following observations. The binding of Fn and collagen has been found to be lower for $S$. aureus grown in milk whey than for those grown in conventional medium. ${ }^{38}$ Also, growth of $S$. aureus on milk agar masked cell wallassociated components (SpA and teichoic acid) and increased expression of $\mathrm{CP} .{ }^{94}$ Few data are available on the regulation of the expression of surface or extracellular components by $S$. aureus. However, it has been demonstrated that the synthesis of a number of exoproteins including $\alpha, \beta$ and $\delta$ toxins, toxic shock syndrome toxin 1 (TSST-1), staphylokinase and SpA was controlled by a locus on the chromosome that was named agr (for accessory gene regulator) and that acts on the transcription of mRNA. ${ }^{101}$ The existence of a regulatory mechanism of the expression of $\mathrm{CP}$ and surface receptors such as Fnbp has yet to be demonstrated.

\section{Pathological modifications to the mammary gland}

S. aureus IMI often start with an acute phase with general (fever and anorexia) and local (congestion and hardness of the udder, milk clots) clinical signs. Thereafter, the infection generally becomes chronic and subclinical with sporadic clinical events. Acute gangrenous IMI characterised by a rapid and massive multiplication of bacteria and a general necrosis of the infected quarter is uncommon in cows but frequent in goats and ewes. ${ }^{20}$

The pathological changes of the mammary gland during $S$. aureus infection have been investigated by microscopic examination of sections of mammary glands either naturally infected ${ }^{102,103}$ or experimentally inoculated with bacteria through the teat canal ${ }^{28,104}$ or into the parenchyma through the skin. ${ }^{45}$ Different histological lesions have been reported. (1) Early ulceration and erosion of lactiferous sinus and ductular epithelia. (2) Infiltration of the parenchyma conjunctive tissue by macrophages and PMNL which cross the mammary epithelium into lactiferous ducts and glandular alveoli. (3) Lesions of the alveolar secretory epithelial cells of variable severity, from a simple decrease of secretory activity to a total cell lysis. (4) Shrinkage of alveoli, proliferation of conjunctive tissue, accumulation of cellular fragments in glandular alveoli as a consequence of the lysis of epithelial cells and PMNL. These phenomena can lead to the oc- 
clusion of alveoli and the trapping of bacteria. The resulting focus of infection can then release bacteria that infect other areas of the gland or can evolve to a granuloma. ${ }^{3}$ An ultrastructural study of the mammary glands of mice experimentally inoculated with $S$. aureus has shown that bacteria can be located in the cytoplasm of epithelial secretory cells. ${ }^{105}$ It would be interesting to know if bovine mammary epithelial cells also possess the ability to phagocytose bacteria, as has been shown for bovine endothelial cells. ${ }^{106}$ This could be studied by using cultured mammary cells and if such is the case, the role of adhesins in the initial adherence of bacteria to cell membrane and of toxins in the subsequent cell lysis must be clarified.

Bacteria are not always present on injured epithelium or tissue. It seems that toxins and enzymes produced by $S$. aureus can diffuse in milk and act at a distance from their site of elaboration. Moreover, lysosomal enzymes released by lysed PMNL could contribute to the alteration of mammary glandular epithelium. ${ }^{104}$

Anderson $^{3,20}$ stressed the dynamic nature of staphylococcal IMI. Pathological modifications affect variable areas of the gland with variable degrees of severity. Conversion of the infection from subclinical to clinical form could reflect the spreading of bacteria through the gland, which depends on the efficiency of local defence mechanisms.

\section{Role of toxins}

$S$. aureus can produce four different haemolytic toxins: $\alpha, \beta, \gamma$ and $\delta$ toxins. Two, $\alpha$ and $\beta$ toxins, appear to play a major role in the virulence of $S$. aureus. $\alpha$ Toxin, which is produced by between $20 \%{ }^{107}$ and c. $50 \%$ (Poutrel, unpublished data) of strains from bovine IMI, is a cytolysin that binds to cell membranes and forms hexameric pores leading to cell death as a consequence of rapid egress of cytoplasmic components. ${ }^{108} \beta$ Toxin, a type $\mathrm{C}$ sphingomyelinase, is produced by $75-100 \%$ of these strains. ${ }^{63,109}$

Early studies have shown that systemic vaccination of goats, ${ }^{110}$ ewes ${ }^{111}$ and cows ${ }^{110}$ with a mixture of $\alpha$ and $\beta$ anatoxins induced serum antibodies specific to $\alpha$ and $\beta$ toxins. Vaccination with anatoxins does not lead to the elimination of experimental $S$. aureus IMI but to a decrease in clinical severity, particularly in small ruminants. This effect can be ascribed to toxin neutralisation by antitoxin antibodies which flow from blood to milk during mammary inflammation. ${ }^{112} \mathrm{Le}$ Gall and Plommet ${ }^{113}$ have observed that the severity of experimental $S$. aureus IMI in non-vaccinated ewes is inversely proportional to blood antitoxin antibody titre. Similarly, the blood antitoxin titre in cows increases with age, whereas the incidence of clinical $S$. aureus IMI decreases. ${ }^{44}$

Several recent studies with experimental inoculations of rabbits and mice have confirmed the role of $\alpha$ and $\beta$ toxins in $S$. aureus IMI. Injection of purified $\alpha$ toxin into rabbit mammary gland caused haemor- rhagic necrosis of the gland whose extent depended on the dose, ${ }^{114}$ whereas injection of purified $\beta$ toxin induced inflammation of the gland, i.e., oedema and a flow of PMNL into mammary ducts and glandular alveoli. Simultaneous injection of both toxins had the same effect as that of purified $\alpha$ toxin alone. ${ }^{114}$ In the rabbit two different forms of $S$. aureus IMI occur: a chronic form with mammary abscesses and a gangrenous form which is often lethal. ${ }^{115}$ Adlam et al. ${ }^{116}$ infected the mammary glands of rabbit does immunised with $\alpha$ or $\beta$ anatoxins and non-immunised controls either with strains BB and Compton 201 isolated from gangrenous IMI or strain CN6708 isolated from chronic IMI. Strain CN6708 produced $\alpha, \beta$, and $\delta$ toxins and strain BB produced $\beta$ toxin, ${ }^{117}$ but no information was given by the authors on toxin expression by strain Compton 201. Strains BB and Compton 201 induced gangrenous IMI in control and $\beta$ anatoxin-immunised rabbits, but chronic IMI in those immunised with $\alpha$ anatoxin, whereas strain CN6708 induced chronic IMI in both control and immunised animals. These results are quite difficult to explain. However, although not investigated or not mentioned by the authors, it can be supposed that strains BB and Compton 201 produced $\alpha$ toxin which is responsible for the gangrenous form of rabbit IMI and that strain CN6708 probably produced a small amount of $\alpha$ toxin. The roles of $\alpha$ and $\beta$ toxins in virulence have been investigated in a mouse model with $S$. aureus mutants. Several studies ${ }^{65,118}$ have shown that mutant strains altered in $\alpha$ toxin expression by chemical mutagenesis were less virulent for mouse mammary gland than the $\alpha$ toxin-producing parental strain. From strains producing $\alpha$ and $\beta$ toxins, Bramley et al. ${ }^{119}$ isolated strains defective in $\alpha$ toxin (non- $\alpha$ ), $\beta$ toxin (non- $\beta$ ) or in both $\alpha$ and $\beta$ toxins (non- $\alpha \beta$ strains) expression by directed mutagenesis. The parental and mutant strains were injected into mouse mammary glands to study bacterial growth and pathological lesions in vivo. It was concluded that necrosis of the mammary gland and the high death rate in mice $(60 \%)$ following inoculation of the parental strain was due to $\alpha$ toxin. Both $\alpha$ and $\beta$ toxins promoted bacterial growth in the mammary gland. However, $\beta$ toxin appear to contribute little to the pathogenesis of acute mastitis in the mouse model. In the case of non- $\alpha \beta$ strains, PMNL and cellular architecture of glandular alveoli were not altered, whereas non- $\beta$ strains caused PMNL lysis, destruction of the secretory epithelium and foci of necrosis. After induction of inflammation by intramammary injection of Escherichia coli lipopolysaccharide, bacterial inoculation caused chronic IMI with all strains, irrespective of toxin expression. Lipopolysaccharide caused an early recruitment of PMNL, which reduced bacterial growth and survival and, therefore, toxin production in milk. This situation, already described, ${ }^{120}$ could represent the natural chronic $S$. aureus IMI commonly observed in cows.

Most $S$. aureus isolates from bovine milk samples 
produced leucocidin under in-vitro conditions. ${ }^{121}$ This toxin, which consists of two separate and synergic components $\mathrm{F}$ and $\mathrm{S},{ }^{122}$ has cytolytic effects on bovine PMNL. ${ }^{123}$ Moreover, it has been shown that cows with chronic $S$. aureus IMI have significant antileucocidin antibody titres in serum and milk, compared with non-infected animals. ${ }^{124}$ The recent cloning and sequencing of leucocidin ${ }^{125}$ should allow sitespecific mutagenesis of the corresponding gene to demonstrate the actual role of leucocidin in the virulence of $S$. aureus during IMI.

A recent study on $262 S$. aureus isolates from bovine IMI has shown that c. $20 \%$ of isolates produced TSST-1, generally in association with enterotoxins C and D. ${ }^{126}$ TSST- 1 is known to induce the release of inflammatory factors such as $\gamma$-interferon and interleukin-1 by human mononuclear cells. ${ }^{127,128}$ Although it is obvious that IMI can be caused by strains which do not produce TSST-1, the role of this toxin has yet to be evaluated.

\section{Role of extracellular enzymes and coagulase}

$S$. aureus produces numerous extracellular enzymes $^{129}$ including hyaluronidase, phosphatase, nuclease, lipase, catalase, staphylokinase and proteases, that have been implicated in the pathogenesis of bovine IMI. The ability of $S$. aureus to multiply rapidly in milk is probably a major component of its virulence. Enzymes could allow S. aureus to use milk substrates for their metabolism and, consequently, to adapt to milk and grow. ${ }^{130}$ However, the involvement of staphylococcal enzymes in the alteration of mammary tissues remains to be demonstrated clearly.

The role of coagulase in the virulence of $S$. aureus has been mostly studied in the mouse. Injection of purified coagulase into the mouse mammary gland caused a PMNL flow into secretory alveoli and hyperplasia of the mammary epithelium. ${ }^{117}$ By means of chemical mutagenesis, Kinsman et al. ${ }^{118}$ have obtained several coagulase-negative $S$. aureus mutant strains from an $\alpha$ toxin-producing parental strain. The loss of coagulase entailed a marked decrease of virulence for mouse mammary gland: coagulasenegative mutant strains caused a moderate mammary alteration, whereas the parental strain caused a generalised necrosis. As coagulase has no necrotising activity, ${ }_{117}$ these observations suggest a synergic effect of coagulase and $\alpha$ toxin. However, Phonimdaeng et $a l .{ }^{131}$ failed to confirm these results with site-specific coagulase mutants. This suggests that the earlier findings ${ }^{118}$ were obtained with strains that had additional mutations on genes encoding other virulence factors. The role of coagulase in bovine IMI remains to be determined. It is noteworthy that most $S$. aureus isolated from bovine IMI coagulate bovine plasma. ${ }^{132}$ However, the relationship between this in-vitro observation and the actual role of coagulase during IMI has never been established.

\section{Conclusions: perspectives of vaccine}

During the past two decades, the mouse mammary gland model has been used extensively to study the virulence factors involved in the pathogenesis of $S$. aureus IMI. This model offers the opportunity to use a large number of animals and given the small size of the glands, to study bacterial growth and the histopathological modifications of the gland in vivo. However, it is likely that results obtained with this model are not fully relevant to natural bovine IMI and, thus, they must always be confirmed by experimental infections of cow udders.

The purpose of vaccination is to increase the efficiency of the natural defences of the mammary gland against $S$. aureus infection. The ideal vaccine must satisfy the following conditions. ${ }^{9}$ (1) It must induce the appropriate type of immune response. (2) Antigens that lead to undesirable side effects must be excluded from the vaccine, particularly those inducing severe inflammation, i.e., delayed hypersensitivity, which can cause damage to secretory tissues and thus compromise milk production. With vaccines containing toxoids and killed pseudocapsule-producing strains, Watson ${ }^{133}$ has shown recently that, following intramammary challenge, vaccinated heifers were more resistant to clinical mastitis and had greater milk production than controls. However, we are convinced that control of immune response and safety of the vaccine could be more easily reached by using selected purified and well-characterised bacterial antigens instead of crude whole-cell preparations.

There is evidence that three major factors could be involved in $S$. aureus virulence: surface protein receptors to host components such as Fnbp, $\mathrm{CP}$ and toxins, particularly $\alpha$ and $\beta$ toxins. Induction in cows of antibodies against these components could lead to several protective effects: inhibition of $S$. aureus adhesion to mammary epithelial cells, suppression of resistance to phagocytosis by PMNL and decrease of tissue lesions by neutralisation of toxins. However, the use in vaccination of surface components not involved in virulence but which are potential targets for opsonising antibodies must not be ruled out.

The multiplication of $S$. aureus in milk before the onset of inflammation is undoubtedly of great importance for the establishment of the infection. It is crucial to obtain a recruitment of activated PMNL into milk of vaccinated animals as early as possible after the entry of $S$. aureus into the mammary gland. This recruitment does not need to be massive as it is likely that a milk SCC of $c .10^{6}$ cells $/ \mathrm{ml}$ is sufficient to impair staphylococcal IMI, ${ }^{22}$ but it must coincide with the presence of opsonising antibodies in milk. The immune-mediated recruitment of PMNL in the bovine mammary gland has been demonstrated clearly by De Cueninck. ${ }^{134}$ In cows sensitised to ovalbumin by subcutaneous injection of this protein during lactation, intramammary infusion of ovalbumin elicited inflammation, i.e., release of PMNL into milk. Such a 
recruitment was not observed in control nonimmunised animals. With a similar experiment in the guinea-pig, De Cueninck has shown that this phenomenon could be transferred by peritoneal cells but not by serum from immunised animals to control animals. ${ }^{135}$ Similarly, Rainard et $a .^{136}$ have recently immunised cows with purified protein $X$, a surface antigen of Str. agalactiae. The inflammatory response of the mammary gland, i.e., PMNL recruitment and bactericidal activity of milk, to an experimental infection by a protein X-bearing strain was earlier and much higher in immunised cows than in control cows. Taken together, these results suggest that PMNL functions, including the recruitment into the lumen of the infected mammary gland and the ability to kill invading bacteria, could be increased by immunocompetent cells, presumably $\mathrm{T}$ lymphocytes, ${ }^{137}$ sensitised by vaccination with bacterial protein antigens. Thus, it would be of great interest to determine if immunisation of cows with $S$. aureus antigens such as Fnbp, anatoxins and CP could induce the recruitment of activated PMNL in the mammary gland during infection by this bacterium.

However, $S$. aureus $\mathrm{CP}$, which do not carry T cellepitopes, are not good immunogens in cows. ${ }^{138} \mathrm{By}$ contrast, conjugation of $\mathrm{CP}$ to a protein carrier, Pseudomonas aeruginosa exotoxin A or diphtheria toxoid, increased their immunogenicity and $\mathrm{T}$ celldependence in mice. ${ }^{139,140}$ Similar results have been obtained recently in cows with a $S$. aureus type $5 \mathrm{CP}$ ovalbumin conjugate. ${ }^{138}$ Furthermore, immunisation of mice led to antibodies that promoted opsonisation of $S$. aureus by human PMNL. ${ }^{139}$

Consequently, a vaccine containing purified surface proteins involved in $S$. aureus adhesion (e.g., Fnbp), $\alpha$ and $\beta$ anatoxins and CP belonging to predominant serotypes and conjugated to one or several of these proteins could be used to immunise cows. ${ }^{9,141}$ It is noteworthy that a recent preliminary study has shown that vaccination of cows with a fusion protein containing the Fn-binding domain of Fnbp lead to significant protection against experimental $S$. aureus IMI, both in terms of clinical signs and reduced SCC. ${ }^{142}$ Several parameters will need to be investigated to guarantee the efficiency of the proposed conjugate vaccine-the conjugation technique, ${ }^{140}$ the route and timing of administration and the adjuvant. Once these parameters of vaccination have been optimised, the efficient protection of cows against $S$. aureus IMI might be feasible.

\section{References}

1. Kloos WE, Schleifer KH. Staphylococcus. In: Sneath PHA, Mair NS, Sharpe ME, Holt JG (eds) Bergey's Manual of systematic bacteriology, vol 2. Baltimore, Williams and Wilkins Co. 1986: 1013-1035.

2. Sheagren JN. Staphylococcus aureus, the persistent pathogen. $N$ Engl J Med 1984; 310: 1368-1373, 1437-1442.

3. Anderson JC. Veterinary aspects of staphylococci. In: Easmon CSF, Adlam C (eds) Staphylococci and staphylococcal infections, vol 1: Clinical and epidemiological aspects. London, Academic Press. 1983: 193-241.

4. Poutrel B. Généralités sur les mammites de la vache laitière. Processus infectieux, épidémiologie, diagnostics, méthodes de contrôle. Rec Med Vet 1985; 161: 497-511.

5. Bramley AJ, Dodd FK. Reviews of the progress in dairy science: mastitis control-progress and prospects. $J$ Dairy Res 1984; 51 : 481-512.

6. Le Louedec C. Efficacité des antibiotiques contre les mammites bovines staphylococciques et streptococciques. Ann Rech Vet 1978; 9: 63-88.

7. Anderson JC. The problem of immunization against staphylococcal mastitis. Br Vet $J 1978 ; 134: 412-420$.

8. Colditz IG, Watson DL. The immunophysiological basis for vaccinating ruminants against mastitis. Aust Vet $J$ 1985; 62: 145-153.

9. Rainard P, Poutrel B. Immunization against mastitis: a practical goal? Flem Vet $J$ 1991; 62 Suppl 1: 141-149.

10. Falkow S. Molecular Koch's postulates applied to microbial pathogenicity. Rev Infect Dis 1988; 10 Suppl 2: S274-S276.

11. Jain NC. Common mammary pathogens and factors in infection and mastitis. J Dairy Sci $1979 ; 62: 128-134$

12. Neave FK. The control of mastitis by hygiene. In: Dodd FH, Jackson ER (eds) Control of bovine mastitis. British Cattle Veterinary Association. 1971: 55.

13. Kingwill RG. The NIRD-CVL mastitis control method. In Mastitis control and herd management. Reading, NIRD. 1981: 24

14. Bramley AJ, King JS, Higgs TM, Neave FK. Colonization of the bovine teat duct following inoculation with Staphylococcus aureus and Escherichia coli. Br Vet J 1979; 135: 149-162.

15. Forbes D. The pathogenesis of bovine mastitis. Vet Bull 1969; 39: 529-541.

16. Du Preez JH. Teat canal infections. Kiel Milchwirtsch Forschungsber 1985; 37: 267-273.

17. Craven N. Do rising fat globules assist microbial invasion via the teat duct between milking? Kiel Milchwirtsch Forschungsber 1985; 37: 554-558.

18. Williams DM, Mein GA. The role of machine milking in the invasion of mastitis organisms and implications for maintaining low infection rates. Kiel Milchwirtsch Forschungsber 1985; 37: 415-425.

19. Prasad LBM, Newbould FHS. Initial response of the bovine mammary gland to invasion by Staphylococcus aureus. Can Vet $J$ 1968; 9: 170-177.

20. Anderson JC. Progressive pathology of staphylococcal mastitis with a note on control, immunisation and therapy. Vet Rec $1982 ; 110: 372-376$.

21. Newbould FHS, Neave FK. The response of the bovine mammary gland to an infusion of staphylococci. $J$ Dairy Res 1965; 32: 163-170.

22. Postle DS, Roguinsky M, Poutrel B. Induced staphylococcal infections in the bovine mammary gland. Am $J$ Vet Res 1978; 39: 29-35.

23. Smith $H$. Microbial surfaces in relation to pathogenicity. Bacteriol Rev 1977; 41 : 475-500.

24. Frost AJ. Selective adhesion of microorganisms to the ductular epithelium of the bovine mammary gland. Infect Immun 1975; 12: 1154-1156.

25. Opdebeeck JP, Frost AJ, O'Boyle D. Adhesion of Staphylococcus aureus and Escherichia coli to bovine udder epithelial cells. Vet Microbiol 1988; 16: 77-86.

26. Frost AJ, Wanasinghe DD, Woolcock JB. Some factors affecting selective adherence of microorganisms in the bovine mammary gland. Infect Immun 1977; 15: 245-253.

27. Wanasinghe DD. Adherence as a prerequisite for infection of the bovine mammary gland by bacteria. Acta Vet Scand $1981 ; 22$ : 109-117.

28. Gudding R, McDonald JS, Cheville NF. Pathogenesis of Staphylococcus aureus mastitis: bacteriologic, histologic. and ultrastructural pathologic findings. Am $J$ Vet Res 1984; 45: 2525-2531.

29. Jonsson P, Wadström T. Cell surface hydrophobicity of 
Staphylococcus aureus measured by the salt agglutination test (SAT). Curr Microbiol 1984; 10: 203-210.

30. Mamo W, Rozgonyi F, Brown A, Hjertén S, Wadström T. Cell surface hydrophobicity and charge of Staphylococcus aureus and coagulase-negative staphylococci from bovine mastitis. J Appl Bacteriol 1987; 62: 241-249.

31. Holderbaum D, Hall GS, Ehrhart LA. Collagen binding to Staphylococcus aureus. Infect Immun 1986; 54: 359-364.

32. Kuusela P. Fibronectin binds to Staphylococcus aureus. Nature 1978; 276: 718-720.

33. Proctor RA. The staphylococcal fibronectin receptor: evidence for its importance in invasive infections. Rev Infect Dis 1987; 9 Suppl 4: S335-S340.

34. Fröman $G$, Switalski LM, Speziale $P$, Höök $M$. Isolation and characterization of a fibronectin receptor from Staphylococcus aureus. J Biol Chem 1987; 262: 6564-6571.

35. Signäs C, Raucci G, Jönsson $\mathrm{K}$ et al. Nucleotide sequence of the gene for a fibronectin-binding protein from Staphylococcus aureus: use of this peptide sequence in the synthesis of biologically active peptides. Proc Natl Acad Sci USA 1989; 86: 699-703.

36. Jönsson K, Signäs C, Müller H-P, Lindberg M. Two different genes encode fibronectin binding proteins in Staphylococcus aureus. The complete nucleotide sequence and characterization of the second gene. Eur J Biochem 1991; 202: 1041-1048.

37. Mamo W, Fröman G, Wadström T. Interaction of subepithelial connective tissue components with Staphylococcus aureus and coagulase-negative staphylococci from bovine mastitis. Vet Microbiol 1988; 18: 163-176.

38. Mamo W, Lindahl M, Jonsson P. Binding of fibronectin and type II collagen to Staphylococcus aureus from bovine mastitis: reduction of binding after growth in milk whey. Microb Pathog 1992; 12: 443-449.

39. Wanasinghe DD. In vitro adherence of Staphylococcus aureus to bovine mammary gland epithelial cells. Acta Vet Scand $1981 ; 22$ : 99-108.

40. Lindahl M, Holmberg O, Jonsson P. Adhesive proteins of haemagglutinating Staphylococcus aureus isolated from bovine mastitis. J Gen Microbiol 1990; 136: 935-939.

41. Sandholm M, Kaartinen L, Hyvönen L, Veijalainen K, Kousa PL. Flotation of mastitis pathogens with cream from subclinically infected quarters. Prospects for developing a cream-rising test for detecting mastitis caused by major mastitis pathogens. Zentralbl Veterinarmed $(B) 1989 ; 36$ : $27-34$.

42. Paape MJ, Wergin WP, Guidry AJ, Pearson RE. Leukocytes - second line of defense against invading mastitis pathogens. J Dairy Sci 1979; 62: 135-153.

43. Schalm OW, Lasmanis J, Jain NC. Conversion of chronic staphylococcal mastitis to acute gangrenous mastitis after neutropenia in blood and bone marrow produced by an equine anti-bovine leukocyte serum. Am J Vet Res 1976; 37: $885-890$

44. Schalm OW, Carroll EJ, Jain NC. Bovine mastitis. Philadelphia, Lea and Febiger. 1971.

45. Heald CW. Morphometric study of experimentally induced Staphylococcus bovis mastitis in the cow. Am J Vet Res 1979; 40: 1294-1298.

46. Roitt I, Brostoff J, Male D. Immunologie fondamentale et appliquée (traduit d l'anglais). Paris, Médecine et Sciences Internationales. 1985.

47. Peterson PK, Wilkinson BJ, Kim Y et al. The key role of peptidoglycan in the opsonization of Staphylococcus aureus. J Clin Invest 1978; 61: 597-609.

48. Wilkinson BJ, Kim Y, Peterson PK, Quie PG, Michael AF. Activation of complement by cell surface components of Staphylococcus aureus. Infect Immun 1978; 20: 388-392.

49. McGuire TC, Musoke AJ, Kurtti T. Functional properties of bovine IgG1 and IgG2: interaction with complement, macrophages, neutrophils and skin. Immunology 1979; 38: 249-256.

50. Watson DL. The effect of cytophilic IgG2 on phagocytosis by ovine polymorphonuclear leucocytes. Immunology 1976; 31: $159-165$.

51. Poutrel B, Caffin JP. A sensitive microassay for the determination of hemolytic complement activity in bovine milk. Vet Immunol Immunopathol 1983; 5: 177-184.

52. Butler JE. Bovine immunoglobulins: an augmented review. Vet Immunol Immunopathol 1983; 4: 43-152.
53. Caffin JP, Poutrel B, Rainard P. Physiological and pathological factors influencing bovine immunoglobulin G1 concentration in milk. $J$ Dairy Sci 1983 ; 66: 2161-2166.

54. Caffin JP, Poutrel B. Physiological and pathological factors influencing bovine immunoglobulin G2 concentration in milk. J Dairy Sci 1988; 71: 2035-2043.

55. Rainard P, Poutrel B, Caffin JP. Assessment of hemolytic and bactericidal complement activities in normal and mastitic bovine milk. J Dairy Sci 1984; 67: 614-619.

56. Paape MJ, Wergin WP. The leukocyte as a defense mechanism. $J$ Am Vet Med Assoc 1977; 170: 1214-1223.

57 Russell MW, Reiter B. Phagocytic deficiency of bovine milk leucocytes: an effect of casein. J Reticuloendothel Soc 1975; 18: $1-13$.

58. Forsgren A, Ghetie V, Lindmark R, Sjöquist J. Protein A and its exploitation. In: Easmon CSF, Adlam C (eds) Staphylococci and staphylococcal infections, vol 2: The organism in vivo and in vitro. London, Academic Press. 1983: 429-480.

59. Lindmark R, Thoren-Tolling K, Sjöquist J. Binding of immunoglobulins to protein $\mathrm{A}$ and immunoglobulin levels in mammalian sera. J Immunol Methods 1983; 62: 1-13.

60. Dossett JH, Kronvall G, Williams RC, Quie PG. Antiphagocytic effects of staphylococcal protein A. $J$ Immunol 1969; 103: 1405-1410.

61. Peterson PK, Verhoef J, Sabath LD, Quie PG. The effect of protein A on staphylococcal opsonization. Infect Immun 1977; 15: 760-764.

62. Kronvall G, Holmberg O, Ripa T. Protein A in Staphylococcus aureus strains of human and bovine origin. Acta Pathol Microbiol Scand (B) 1972; 80: 735-742.

63. Poutrel B, Ducelliez M. Evaluation of three rapid tests for identification of Staphylococcus aureus isolated in bovine milk. Ann Rech Vet 1979; 10: 125-129.

64. Goudswaard J, Van der Donk JA, Noordzij A, van Dam RH, Vaerman JP. Protein A reactivity of various mammalian immunoglobulins. Scand J Immunol 1978; 8: 21-28.

65. Jonsson P, Lindberg M, Haraldsson I, Wadström T. Virulence of Staphylococcus aureus in a mouse mastitis model: studies of alpha hemolysin, coagulase and protein $\mathrm{A}$ as possible virulence determinants with protoplast fusion and gene cloning. Infect Immun 1985; 49: 765-769.

66. Foster TJ, O'Reilly M, Phonimdaeng P, Cooney J, Patel AH, Bramley AJ. Genetic studies of virulence factors of Staphylococcus aureus. Properties of coagulase and $\gamma$-toxin and the role of $\alpha$ toxin, $\beta$ toxin, and protein $A$ in the pathogenesis of $S$. aureus infections. In: Novick RP (ed) Molecular biology of the staphylococci. New York, VCH. 1990: 403-417.

67. Wilkinson BJ. Staphylococcal capsules and slime. In: Easmon CSF, Adlam C (eds) Staphylococci and staphylococcal infections, vol 2: The organism in vivo and in vitro. London, Academic Press. 1983: 481-523.

68. Melly MA, McGee ZA, Horn RG, Morris F, Glick AD. An electron microscopic india ink technique for demonstrating capsules on microorganisms: studies with Streptococcus pneumoniae, Staphylococcus aureus, and Neisseria gonorrhoeae. J Infect Dis 1979; 140: 605-609.

69. Yoshida K, Ekstedt RD. Relation of mucoid growth of Staphylococcus aureus to clumping factor reaction, morphology in serum-soft agar, and virulence. $J$ Bacteriol 1968; 96: 902-908.

70. Yoshida K, Smith MR, Naito Y. Biological and immunological properties of encapsulated strains of Staphylococcus aureus from human sources. Infect Immun 1970; 2: 528-532.

71. Smith MR, Yoshida K, Naito Y. Use of the clumping factor reaction for the identification of encapsulated strains of Staphylococcus aureus from human sources. Infect Immun 1971; 3: 707-708.

72. Norcross NL, Opdebeeck JP. Encapsulation of Staphylococcus aureus isolated from bovine milk. Vet Microbiol 1983; 8: 397-404.

73. Opdebeeck JP, Norcross NL. Frequency and immunologic cross-reactivity of encapsulated Staphylococcus aureus in bovine milk in New York. Am J Vet Res 1983; 44: 936-988.

74. Opdebeeck JP, Frost AJ, O'Boyle D. Adhesion of Staphylococcus aureus and Escherichia coli to bovine udder epithelial cells. Vet Microbiol 1988; 16: 77-86.

75. Anderson JC. Absence of encapsulation in strains of Staphy- 
lococcus aureus isolated from bovine mastitis. Res Vet Sci 1984; 37: 359-361.

76. Rather PN, Davis AP, Wilkinson BJ. Slime production by bovine milk Staphylococcus aureus and identification of coagulase-negative staphylococcal isolates. $J$ Clin Microbiol $1986 ; 23$ : 858-862.

77. Watson DL, Prideaux JA. Comparisons of Staphylococcus aureus grown in vitro or in vivo. Microbiol Immunol 1979; 23: $543-547$.

78. Watson DL. Virulence of Staphylococcus aureus grown in vitro or in vivo. Res Vet Sci 1982; 32: 311-315.

79. Watson DL, Watson NA. Expression of pseudocapsule by Staphylococcus aureus: influence of culture medium and relevance to mastitis. Res Vet Sci 1989; 47: 152-157.

80. Karakawa WW, Vann WF. Capsular polysaccharides of Staphylococcus aureus. Semin Infect Dis 1982; 4: 285-293.

81. Watson DL. Evaluation of attenuated, live staphylococcal mastitis vaccine in lactating heifers. $J$ Dairy $S c i$ 1984; 67: 2608-2613.

82. Watson DL. Vaccination against experimental staphylococcal mastitis in ewes. Res Vet Sci 1988; 45: 16-21.

83. Sompolinsky D, Samra Z, Karakawa WW, Vann WF, Schneerson R, Malik Z. Encapsulation and capsular types in isolates of Staphylococcus aureus from different sources and relationship to phage types. J Clin Microbiol $1985 ; 22$ : 828-834.

84. Arbeit RD, Karakawa WW, Vann WF, Robbins JB. Predominance of two newly described capsular polysaccharide types among clinical isolates of Staphylococcus aureus. Diagn Microbiol Infect Dis 1984; 2: 85-91.

85. Hochkeppel HK, Braun DG, Vischer W et al. Serotyping and electron microscopy studies of Staphylococcus aureus clinical isolates with monoclonal antibodies to capsular polysaccharide types 5 and 8 . J Clin Microbiol $1987 ; 25$ 526-530.

86. Fournier JM, Bouvet A, Boutonnier A et al. Predominance of capsular polysaccharide type 5 among oxacillin-resistant Staphylococcus aureus. $J$ Clin Microbiol 1987; 25 1932-1933.

87. Fournier J-M, Vann WF, Karakawa WW. Purification and characterization of Staphylococcus aureus type 8 capsular polysaccharide. Infect Immun 1984; 45: 87-93.

88. Fournier JM, Hannon K, Moreau M, Karakawa WW, Van WF. Isolation of type 5 capsular polysaccharide from Staphylococcus aureus. Ann Inst Pasteur Microbiol 1987, 138: 561-567.

89. Vann WF, Moreau M, Sutton R, Byrd RA, Karakawa WW. Structure and immunochemistry of Staphylococcus aureus capsular polysaccharide. UCLA Symp Mol Cell Biol New Ser 1988; 64: 187-198.

90. Karakawa WW, Sutton A, Schneerson R, Karpas A, Vann WF Capsular antibodies induce type-specific phagocytosis of capsulated Staphylococcus aureus by human polymorphonuclear leukocytes. Infect Immun 1988; 56: 1090-1095.

91. Poutrel B, Boutonnier A, Sutra L, Fournier JM. Prevalence of capsular polysaccharide types 5 and 8 among Staphylococcus aureus isolates from cow, goat and ewe milk. $J$ Clin Microbiol 1988; 26: 38-40.

92. Sutra L, Mendolia C, Rainard P, Poutrel B. Encapsulation of Staphylococcus aureus isolates from mastitic milk: relationship between capsular polysaccharide types 5 and 8 and colony morphology in serum-soft agar, clumping factor, teichoic acid and protein A. J Clin Microbiol 1990; 28: 447-451.

93. Sutra L, Poutrel B. Capsular polysaccharides of Staphylococcus aureus isolates from mastitic milk. In: Jeljaszewicz $\mathrm{J}$ Ciborowski P (eds) The staphylococci. Zentralbl Bakteriol 1991; Suppl 21: 161 .

94. Sutra L, Rainard P, Poutrel B. Phagocytosis of mastitis isolates of Staphylococcus aureus and expression of type 5 capsular polysaccharide are influenced by growth in the presence of milk. J Clin Microbiol 1990; 28: 2253-2258.

95. Peterson PK, Wilkinson BJ, Kim Y, Schmeling D, Quie PG. Influence of encapsulation on staphylococcal opsonization and phagocytosis by human polymorphonuclear leukocytes. Infect Immun 1978; 9: 943-949.

96. King BF, Wilkinson BJ. Binding of human immunoglobulin $\mathrm{G}$ to protein A in encapsulated Staphylococcus aureus. Infect Immun $1981 ; 33: 666-672$
97. Xu S, Arbeit RD, Lee JC. Phagocytic killing of encapsulated and microencapsulated Staphylococcus aureus by human polymorphonuclear leukocytes. Infect Immun 1992; 60: 1358-1362.

98. Van Oss CJ. Phagocytosis as a surface phenomenon. Ann Rev Microbiol 1978; 32: 19-39.

99. Sutra L, Poutrel B. Detection of capsular polysaccharide in milk of cows with natural intramammary infection caused by Staphylococcus aureus. Am J Vet Res 1990; 51: 1857-1859.

100. Johne B, Jarp J, Haaheim LR. Staphylococcus aureus exopolysaccharide in vivo demonstrated by immunomagnetic separation and electron microscopy. J Clin Microbiol 1989 27: $1631-1635$.

101. Recsei P, Kreiswirth B, O'Reilly M, Schlievert P, Gruss A, Novick RP. Regulation of exoprotein gene expression in Staphylococcus aureus by agr. Mol Gen Genet 1986; 202 . 58-61.

102. Chandler RL, Reid IM. Ultrastructural and associated observations on clinical cases of mastitis in cattle. J Comp Pathol 1973; 83: 233-241.

103. Sordillo LM, Doymaz MZ, Oliver SP. Morphological study of chronic Staphylococcus aureus mastitis in the lactating bovine mammary gland. Res Vet Sci 1989; 47: 247-252.

104. Nickerson SC, Heald CW. Histopathologic response of the bovine mammary gland to experimentally induced Staphylococcus aureus infection. Am J Vet Res $1981 ; 42$ 1351-1355.

105. Chandler RL, Smith K, Turfrey BA. Studies on the phagocytic potential of secretory epithelial cells in experimental mastitis. J Comp Pathol 1980; 90 : 385-394.

106. Vann JM, Proctor RA. Ingestion of Staphylococcus aureus by bovine endothelial cells results in time- and inoculumdependent damage to endothelial cell monolayers. Infect Immun 1987; 55: 2155-2163.

107. Elek SD, Levy E. Distribution of haemolysis in pathogenic and non-pathogenic staphylococci. J Pathol Bacteriol 1950 ; 62: $541-554$.

108. Bhakdi S, Tranum-Jensen J. Alpha-toxin of Staphylococcus aureus. Microbiol Rev 1991; 55: 733-751.

109. Hajek V, Marsalek E. A study of staphylococci of bovine origin Staphylococcus aureus var. bovis. Zentralbl Bakteriol [Orig] A 1969; 209: 154-160.

110. Derbyshire JB. Studies in immunity to experimental staphylococcal mastitis in the goat and the cow. J Comp Pathol Ther 1960; 70: 222-231.

111. Plommet M, Le Gall A. Mammite staphylococcique de la brebis. III. Recherches sur l'immunité antitoxique et antimicrobienne. Ann Inst Pasteur 1963; 104: 779-796.

112. Adlam C, Ward PD, Turner WH, Craig GR, Edkins S Knights JM. The role of toxins and antitoxins in staphylococcal mastitis. Zentralbl Bakteriol Mikrobiol Hyg 1981; Suppl 10: 647-650.

113. Le Gall A, Plommet M. Observations sur la croissance des staphylocoques et al réaction leucocytaire au cours des premières heures de al mammite expérimentale de la brebis. Ann Biol Anim Bioch Biophys 1965; 5: 113-130.

114. Ward PD, Adlam C, McCartney AC, Arbuthnott JP, Thorley CM. A histopathological study of the effects of highly purified staphylococcal alpha and beta toxins on the lactating mammary gland and skin of the rabbit. $J$ Comp Pathol 1979; 89: 169-177.

115. Adlam C, Thorley CM, Ward PD, Collins M, Lucken RN, Knight PA. Natural and experimental staphylococcal mastitis in rabbits. J Comp Pathol 1976; 86: 581-593.

116. Adlam C, Ward PD, McCartney AC, Arbuthnott JP, Thorley CM. Effect of immunization with highly purified alphaand beta-toxins on staphylococcal mastitis in rabbits Infect Immun 1977; 17: 250-256.

117. Anderson JC, Adlam C, Knights JM. The effect of staphylocoagulase in the mammary gland of the mouse. Br J Exp Pathol 1982; 63: 336-340.

118. Kinsman O, Jonsson P, Haraldsson I, Lindberg M, Arbuthnott JP, Wadström T. Decreased virulence of alpha haemolysin negative and coagulase negative mutants of Staphylococcus aureus in experimental mastitis in mice. Zentralbl Bakteriol Mikrobiol Hyg 1981; Suppl 10 651-659.

119. Bramley AJ, Patel AH, O'Reilly M, Foster R, Foster TJ. Roles of alpha-toxin and beta-toxin in virulence of Staphy 
lococcus aureus for the mouse mammary gland. Infect Immun 1989; 57: 2489-2494.

120. Anderson JC. Experimental staphylococcal mastitis in the mouse: the induction of chronic mastitis and its response to antibiotic therapy. J Comp Pathol 1977; 87: 611-621.

121. Loeffler DA, Norcross NL, Opdebeeck JP. Determination by enzyme-linked immunosorbent assay of the optimal dose of staphylococcal leukocidin for systemic immunization of dairy cows. Am J Vet Res 1988; 49: 1452-1455.

122. Woodin AM. Staphylococcal leucocidin. In: Cohen JO (ed) The staphylococci. New York, Wiley Intersciences. 1972: 281-299.

123. Loeffler DA, Schat KA, Norcross NL. Use of ${ }^{51} \mathrm{Cr}$ release to measure the cytotoxic effects of staphylococcal leukocidin and toxin neutralization on bovine leukocytes. $J$ Clin Microbiol 1986; 23: 416-420.

124. Loeffler DA, Norcross NL. Enzyme-linked immunosorbent assay for detection of milk immunoglobulins to leukocidin toxin of Staphylococcus aureus. Am J Vet Res 1985; 46: 1728-1732.

125. Supersac G, Prevost G, Piemont Y. Sequencing of leucocidin $\mathrm{R}$ from Staphylococcus aureus P83 suggests that staphylococcal leucocidins and gamma-hemolysin are members of a single, two-component family of toxins. Infect Immun 1993; 61: 580-587.

126. Kenny K, Reiser RF, Bastida-Corcuera FD, Norcross NL. Production of enterotoxins and toxic shock syndrome toxin by bovine mammary isolates of Staphylococcus aureus. J Clin Microbiol 1993; 31: 706-707.

127. Ikejima T, Okusawa JW, van der Meer JWM, Dinarello CA. Induction by toxic-shock-syndrome toxin-1 of a circulating tumor necrosis factor-like substance in rabbits and of immunoreactive tumor necrosis factor and interleukin-1 from human mononuclear cells. J Infect Dis 1988; 158: 1017-1025.

128. Micusan VV, Desrosiers M, Gosselin J et al. Stimulation of T cells and induction of interferon by toxic shock syndrome toxin 1. Rev Infect Dis 1989; 11 Suppl 1: S305-S312.

129. Arvidson SO. Extracellular enzymes of Staphylococcus aureus. In: Easmon CSF, Adlam C (eds) Staphylococci and staphylococcal infections, vol 2: The organism in vivo and in vitro. London, Academic Press. 1983: 745-808.
130. Anderson JC. Mechanisms of staphylococcal virulence in relation to bovine mastitis. Br Vet $J$ 1976; 132: 229-245.

131. Phonimdaeng P, O'Reilly M, Nowlan P, Bramley AJ, Foster TJ. The coagulase of Staphylococcus aureus 8325-4. Sequence analysis and virulence of site-specific coagulasedeficient mutants. Mol Microbiol 1990; 4: 393-404.

132. Hajek V, Marsalek E. Evaluation of classifactory criteria for staphylococci. Zentralbl Bakteriol Hyg 1976; Suppl 5: $11-21$.

133. Watson DL. Vaccination against experimental staphylococcal mastitis in dairy heifers. Res Vet Sci 1992; 53: 346-353.

134. De Cueninck BJ. Immune-mediated inflammation in the lumen of the bovine mammary gland. Int Arch Allergy Appl Immunol 1979; 59: 394-402.

135. De Cueninck B. Expression of cell-mediated hypersensitivity in the lumen of the mammary gland in guinea pigs. $\mathrm{Am} \mathrm{J}$ Vet Res 1982; 43: 1696-1700.

136. Rainard P, Lautrou Y, Sarradin P, Coulibaly A, Poutrel B. The kinetics of inflammation and phagocytosis during bovine mastitis induced by Streptococcus agalactiae bearing the protein X. Vet Res Commun 1991; 15: 163-176.

137. Campbell PA. The neutrophil, a professional killer of bacteria, may be controlled by T cells. Clin Exp Immunol 1990; 79: $141-143$.

138. Gilbert FB, Poutrel B, Sutra L. Immunogenicity in cows of Staphlococcus aureus type 5 capsular polysaccharideovalbumin conjugate. Vaccine (in press).

139. Fattom A, Schneerson R, Szu SC et al. Synthesis and immunologic properties in mice of vaccines composed of Staphylococcus aureus type 5 and type 8 capsular polysaccharides conjugated to Pseudomonas aeruginosa exotoxin A. Infect Immun 1990; 58: 2367-2374.

140. Fattom A, Shiloach J, Bryla D et al. Comparative immunogenicity of conjugates composed of the Staphylococcus aureus type 8 capsular polysaccharide bound to carrier proteins by adipic acid dihydrazide or $\mathrm{N}$ succinimidyl-3-(2-pyridyldithio)propionate. Infect Immun 1992; 60: 584-589.

141. Foster TJ. Potential for vaccination against infections caused by Staphylococcus aureus. Vaccine 1991; 9: 221-227.

142. Nelson LF, Flock JL, Höök $M$, Lindberg $M$, Müller HP, Wadström T. Adhesins in staphylococcal mastitis as vaccine components. Flem Vet J 1991; 62 Suppl 1: $111-125$. 